\title{
Molars and incisors: show your microarray IDs
}

Virginie Laugel-Haushalter ${ }^{1}$, Marie Paschaki ${ }^{1}$, Christelle Thibault-Carpentier ${ }^{2}$, Doulaye Dembelé ${ }^{2}$ Pascal Dollé ${ }^{1}$ and Agnès Bloch-Zupan 1,3,4*

\begin{abstract}
Background: One of the key questions in developmental biology is how, from a relatively small number of conserved signaling pathways, is it possible to generate organs displaying a wide range of shapes, tissue organization, and function. The dentition and its distinct specific tooth types represent a valuable system to address the issues of differential molecular signatures. To identify such signatures, we performed a comparative transcriptomic analysis of developing murine lower incisors, mandibular molars and maxillary molars at the developmental cap stage (E14.5).

Results: 231 genes were identified as being differentially expressed between mandibular incisors and molars, with a fold change higher than 2 and a false discovery rate lower than 0.1 , whereas only 96 genes were discovered as being differentially expressed between mandibular and maxillary molars. Numerous genes belonging to specific signaling pathways (the Hedgehog, Notch, Wnt, FGF, TGF $\beta / B M P$, and retinoic acid pathways), and/or to the homeobox gene superfamily, were also uncovered when a less stringent fold change threshold was used.

Differential expressions for 10 out of 12 (mandibular incisors versus molars) and 9 out of 10 selected genes were confirmed by quantitative reverse transcription-PCR (qRT-PCR). A bioinformatics tool (Ingenuity Pathway Analysis) used to analyze biological functions and pathways on the group of incisor versus molar differentially expressed genes revealed that 143 genes belonged to 9 networks with intermolecular connections. Networks with the highest significance scores were centered on the TNF/NFKB complex and the ERK1/2 kinases. Two networks ERK1/2 kinases and tretinoin were involved in differential molar morphogenesis.
\end{abstract}

Conclusion: These data allowed us to build several regulatory networks that may distinguish incisor versus molar identity, and may be useful for further investigations of these tooth-specific ontogenetic programs. These programs may be dysregulated in transgenic animal models and related human diseases leading to dental anomalies.

Keywords: Tooth development, Molar, Incisor, Gene expression, Mouse, Microarray

\section{Background}

A key question in developmental biology is how several shared molecular pathways can give rise to distinct organs, differing in their shape and tissue organization. The dentition represents a valuable system to address the issue of differential gene expression leading to the generation of specific tooth types. The mouse dentition

\footnotetext{
* Correspondence: agnes.bloch-zupan@unistra.fr

'Developmental Biology and Stem Cells Department, Institut de Génétique et de Biologie Moléculaire et Cellulaire (IGBMC), Centre National de la Recherche Scientifique (UMR 7104), Institut National de la Santé et de la Recherche Médicale (U 964), Fédération de Médecine Translationnelle de Strasbourg (FMTS), Université de Strasbourg, BP 10142, 1 rue Laurent Fries, Illkirch Cedex 67404, France

${ }^{3}$ University of Strasbourg, Faculty of Dentistry, 1 place de l'Hôpital, Strasbourg, France

Full list of author information is available at the end of the article
}

is composed of one incisor and three molars on each hemiquadrant, separated by a toothless gap called diastema. Although molars and incisors develop according to the same basic developmental sequences, they display several important differences. Rodent incisors have a continuously growing ability through life, linked to the presence of an active stem cell niche located within the apical cervical loops [1]. They also exhibit asymmetrical development: ameloblasts differentiate and deposit enamel matrix only on the labial side, whereas the lingual side functions as a root analogue generating odontoblasts [2].

Odontogenesis proceeds through several stages. It initiates at the dental lamina stage by the appearance of a thickened area in the oral ectoderm, and proceeds to bud, cap and bell stages, odontoblasts and ameloblasts terminal differentiations, dentin and enamel matrix deposition and

\section{() Biomed Central}


mineralization, root formation and finally tooth eruption. Odontogenesis is controlled by epithelio-mesenchymal interactions between neural crest-derived ectomesenchymal cells and oral ectoderm [3-9], and is regulated by conserved signaling pathways (FGF, BMP, Shh, Wnt, TGF $\beta$, Notch, TNF/NFkB) [10-16]. Transcription factors including several homeobox gene products [17-21] and genes from the retinoic acid pathway [22] also play a role in tooth development.

The differential location, identity, shape and size of teeth are determined by several pathways acting at early stages of development [23]. At mouse embryonic day E10.5 the first molecular signals (BMP4, FGF8) initiating differential tooth morphogenesis are found in the oral ectoderm in mutually exclusive and complementary territories $[9,24]$, which will trigger subsequent mesenchymal signaling. Already at this stage presumptive molar and incisor fields are well defined [25]. Tooth development was postulated not to involve any Hox (Antennapedia-like homeobox) gene [26], although recent studies showed specific expression of some Hox genes in distinct tooth bud tissues [27]. A number of other homeobox genes are expressed, however, in nested patterns across the developing jaws. The mandible is divided into oral (expressing $L h x 6$ and 7), aboral (expressing Gsc), distal (presumptive incisor, expressing $M s x 1$ and 2) and proximal (presumptive molar, expressing $D l x 1$ and 2, Barx1, Pitx1) domains [17-19]. These expression patterns are defined by positive and negative signals from the oral epithelium. Bmp4, for example, is initially expressed in the distal epithelium and induces expression of Msx 1 in the underlying (presumptive incisor) mesenchyme, while at the same time it negatively regulates expression of Barx1, so as to restrict its expression to the presumptive molar region [18]. Fgf8, meanwhile, is expressed adjacent to Bmp4 in the proximal oral epithelium and positively induces Barx 1 expression in the underlying presumptive molar epithelium [18]. Other genes display also a differential expression pattern [28,29].

Tooth shape specification from the dental lamina stage is contained within the ectomesenchyme. At the cap stage (E14.5 in the mouse) the condensing dental mesenchymal papilla controls the growth and folding of the inner dental epithelium. Mesenchymal signals induce within the enamel organ the formation of a signaling center called the primary enamel knot. It is a transitory structure of non proliferative cells, which produces several signaling molecules [30] and is essential to crown and cusps development and shape. The patterning role of the mesenchyme and dental papilla has also been addressed by heterologous recombination experiments from E13 to E16 between molar and incisor dental papilla and enamel organs, allowing the development of teeth of shape and type corresponding to the mesenchymal identity $[31,32]$.
Many genes have a dynamic expression pattern during odontogenesis, and by the E14.5 cap stage a lot of genes that have earlier been linked to either the incisor or molar regions are expressed in all tooth germs and may not anymore be differentially expressed.

Alterations of these precisely regulated molecular and cellular sequences of development lead to dental anomalies, i.e. anomalies of teeth number, shape and size, of hard structures (enamel and dentin), of root formation and eruption. These malformations are observed in transgenic mouse models [33,34] mimicking human diseases and within the clinical phenotypes of syndromes or rare genetic diseases [35,36]. Indeed, at least 900 of the $\sim 7000$ known rare diseases or syndromes include oro-dental anomalies. In some syndromes only molars and canines are affected, like in oto-dental syndrome caused by deletions of the FGF3 gene and characterized by grossly enlarged molar teeth (globodontia) [37]. In other syndromes, only incisors are affected like in KBG syndrome caused by mutation in ANKRD11 and characterized by intellectual disability associated with short stature, facial dysmorphism and macrodontia of the upper central incisors, often with an agenesis of maxillary lateral incisors [38]. SATB2 was involved in dental anomalies like incisor agenesis both in human in the 2q33.1 microdeletion syndrome [39] and in the corresponding mouse model [40]. We also recently identified $S M O C 2$, a gene causing when mutated severe developmental dental defects with a dentin dysplasia phenotype associated to major microdontia, oligodontia, and shape abnormalities [41]. Furthermore, we showed a differential expression of this gene between molars and incisors.

In order to discover new candidate genes involved in the molecular events responsible for differential histomorphogenesis of the molars and incisors, we performed a transcriptomic analysis of developing murine lower incisors, mandibular molars and maxillary molars at the cap stage of development (E14.5). Here we report a global analysis of the identified differentially expressed genes. These data allowed us to build several regulatory networks that may distinguish incisor versus molar development, and may be useful for further investigations of these tooth-specific ontogenetic programs, some of which may be dysregulated in human diseases.

\section{Results and discussion}

\section{Analysis of tooth specific transcriptional profiles}

We decided to compare gene expression profiles in developing murine lower incisor and molars, as well as between the lower and upper (mandibular and maxillary) first molars. The developing tooth buds were collected by microdissection from E14.5 wild-type C57BL6 mice, and total RNA was extracted with the RNAeasy micro Kit (Qiagen, see Materials and Methods), after pooling 4 
tooth germs per sample in order to obtain enough RNA for microarray hybridization. Altogether, 4 lower incisors samples, 4 maxillary molars samples, and 8 mandibular molars samples were hybridized on Affymetrix mouse gene 1.0 ST microarrays. Principal component analysis (PCA) was performed using the Partek Software to assess the consistency of the results. According to this analysis, the transcriptional profiles of three incisors samples (one sample of dubious quality was discarded) and eight mandibular molars samples showed that samples segregated in two distinct groups, showing relevant transcriptional differences between mandibular molars and lower incisors (Additional file 1). PCA performed on transcriptional profiles of eight mandibular molars samples and four maxillary molars samples also showed a clear segregation of samples between the two groups. This analysis indicated that transcriptional differences existed both between lower incisors and molars, as well as between mandibular and maxillary molars.

Our microarray data analysis allowed identification of several genes already known to be involved in tooth development (see Introduction), which did not show statistically different expression levels between distinct tooth samples. For instance, there was no significant difference in Bmp4, Fgf8, Msx1, Pitx1, Pitx2, Gsc, Dlx2, Runx2, Msx2, Lhx6, Hand1 or Satb2 expression between lower incisors and mandibular molars, and in Bmp4, Fgf8, Msx1, Dlx2, Runx2, Msx2 and Satb2 expression between mandibular and maxillary molars. Altogether, these data validated the sensitivity of the microarray analysis, and confirmed that several important regulators of tooth development were expressed at comparable levels in distinct tooth types at the stage analyzed.

Many genes exhibited statistically significant differential expression levels between specific tooth types. The distribution of differentially expressed genes is illustrated in Figure 1A (mandibular incisor versus first molar) and 1B (mandibular versus maxillary first molar). In these diagrams - as well as in all subsequent Tables-negative "fold changes" reflect an enriched expression in incisor (Figure 1A) or in maxillary molar (Figure 1B), whereas positive values indicate an enriched expression in mandibular molar. Genes plotted in red are those exhibiting a fold change superior to 2 (> 2 fold change) between the two types of samples (with statistical significance). We focused our analysis on such genes exhibiting at least a 2 fold change in expression in a given tooth type. However, in order not to overlook genes that may be relevant even if their differential expression is not as pronounced, we also considered all genes belonging to specific signaling pathways (the Hedgehog, Notch, Wnt, FGF, TGF $\beta / B M P$, and retinoic acid pathways) and/or to the homeobox gene superfamily, as many important regulators of tooth development belong to these families. For analysis of these selected pathways and gene families, we applied a less stringent threshold (+ or -1.2 fold change). For all identified genes we performed a detailed analysis of the literature, and hereby distinguish genes previously reported to be expressed (and sometimes functionally involved) in tooth development-including rare cases of reported differential expression between tooth types-from new candidate genes potentially involved in establishing tooth-specific programs.

\section{Expression profiling of mandibular molars versus incisors Genes with a fold change higher than 2}

Among the 35,556 probe sets represented in the microarrays, about $10 \%$ of the genes were excluded for any further analysis because of their low expression level, and 231 genes were differentially expressed between mandibular
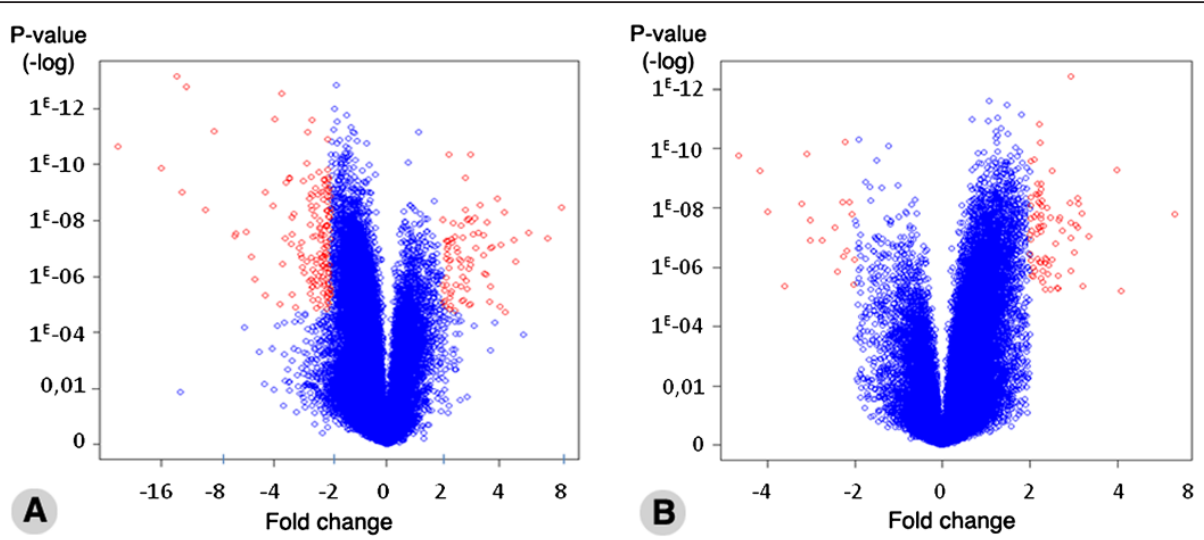

Figure 1 Overview of gene expression changes in mandibular molars vs. incisors (A) and mandibular vs. maxillary molars (B). Genes are plotted (Volcano plot) according to their fold change in mRNA expression (abscissae) and the corrected p-values from Student t-test (ordinates). In both plots, positive values correspond to genes more highly expressed in mandibular molars, and negative values to genes enriched in expression in incisors (A) or maxillary molars (B). Genes with a fold change in expression higher than 2 and a false discovery rate lower than 0.1 are shown in red. 
incisor and molar, with a fold change higher than 2 and a false discovery rate lower than 0.1 (corresponding to a p-value lower than 6.89E-04) (Figure 1A). The top ten genes exhibiting the highest expression in mandibular molars were Barx1, C1qtnf3, Adcy8, Cntn6, Six2, Tcfap2b, Odz1, Vstm2a, Nptx1 and Has2. The top ten genes showing highest expression in incisors were Hpse2, Alx1, Hand2, Sfrp4, Pax3, Alx3, Isl1, Mcpt2, Cacna2d3 and Irx4 (Table 1A). Interestingly, among these genes, four were already known to be differentially expressed, with Barx 1 and Six2 preferentially expressed in molars [42,43] and Isl1 and Hand2 in incisors $[29,44]$.

Additional literature searches revealed that, among the remaining 231 genes, only 22 were previously described as being expressed during tooth development, including 9 genes known to be differentially expressed between molar and incisors. Thus, our analysis revealed nearly 200 "new", potentially interesting genes not previously described as differentially expressed between developing incisors and molars (a complete list is given in Additional file 2). Table 1B provides data for selected genes with high fold change and/or belonging to families for which other member(s) are involved in odontogenesis. Sfrp 2 and Sfrp4, for example, belong to the family of secreted frizzledrelated proteins, for which $S f p r 1$ was already known to be expressed in teeth $[65,66]$. Tlx2 and Bmp5 also have two paralogues, $T l x 1$ and $B m p 4$, that were previously described as being differentially expressed between tooth types [62,67]. Two $A l x$ genes, $A l x 1$ and $A l x 3$ were differentially expressed in our microarray experiments, with very high fold changes. The corresponding human genes are mutated in frontonsal dysplasia affecting the midline facial structures [68]. We also found two members of the Iroquois homeobox gene family, Irx4 and Irx6, suggesting a role of these genes in defining incisor identity.

\section{Genes from selected pathways or families}

From the 3078 genes exhibiting a fold change higher than 1.2 and a false discovery rate lower than 0.1, 107 belonged to pathways or families selected as being important for tooth development (the FGF, TGF $\beta / B M P$, Wnt, Hedgehog, retinoic acid, and Notch pathways, and the homeobox gene superfamily: see Introduction). Among these, 88 had not been reported to be expressed in teeth and were considered as new potential genes involved in tooth development (Table 2). Nineteen genes were already known to be expressed in teeth (Table 2, gene names in bold), and among them 11 were known to be differentially expressed between the two tooth types (Table 2, underlined). Considering genes not previously known to be expressed in teeth, and genes not yet described to be differentially expressed between tooth types, we found in total 99 genes not yet involved in differential tooth morphogenesis.

\section{Quantitative RT-PCR analysis}

Twelve of these 99 genes were selected for validation of the microarray data by quantitative RT-PCR (qRT-PCR). These were candidates from interesting signaling pathways: Ihh (from the hedgehog pathway), Dll1 (from the Notch pathway), Sfrp1 and Sfrp2 (from the Wnt pathway), Fgf12 (from the FGF pathway), Bmp5 (from the TGF $\beta$ pathway/superfamily), Cyp26c1 and Cyp1b1 (encoding two retinoic acid-metabolizing enzymes), Alx1 and Shox 2 (members of the homeobox gene superfamily). We also decided to verify two genes known to be expressed in teeth and exhibiting a fold change higher than 2: Smoc2 because we recently detected by in situ hybridization a differential expression between molars and incisors [41] and Prkcq, which belongs to the NFKB pathway (Table 1B). qRT-PCR was performed on RNA samples distinct from those used for microarray hybridization. From these 12 genes, 10 were found to be differentially expressed between molar and incisors by qRT-PCR, in agreement with the microarray data (Figure 2). The two exceptions were Ihh, which did not exhibit differential expression, and Dll1, which displayed an opposite expression (molar > incisor, not statistically significant) when compared to the microarray data.

\section{Gene network analysis}

Relevant networks when considering all genes with a fold change higher than 2 To gain insight into interactions that may occur between the differentially expressed genes and/or proteins, we constructed biologically relevant networks using the Ingenuity pathway analysis software. From the 231 differentially expressed genes with a fold change higher than 2, 143 genes were mapped in nine networks. The most relevant network (score=48) was centered on the NFkB complex and contained 24 differentially expressed genes (Figure 3A). Barx1, Dlx1, Sox2, Cited1, Nr2f1, Nr2f2, Vsnl1, Cxcl6, Dusp6, Has2, Lpl, Tfap2b, Rgs5, Sfrp1 and Sfrp2 were more strongly expressed in mandibular molars than in incisors. Otx1, Isl1, Cyp2c19, Foxa3, Pappa, Rgs7, Rgs20, Cyp17a1 and Sfrp4 were more expressed in incisors. This network highlighted two genes from the nuclear receptor superfamily (Nr2f1 and Nr2f2, also known as COUP-TFI and II), both expressed at higher levels in molars. On the other hand, several genes from the Sfrp family were differentially expressed, with Sfrp1 and Sfrp2 being more expressed in mandibular molars and Sfrp 4 more expressed in incisors (Figure 3A). The second network (score $=42$ ) was centered on ERK1/2 and contained 22 differentially expressed genes (Figure 3B). Hdac9, Entpd1, Ampa Receptor, Grp and Gria2 were expressed at higher levels in mandibular molars, whereas Hand1, Hand2, Myocd, Cacna1d, Ppargc1a, C1qtnf2, Ptprr, Ace2, Nts, SSt, Alx3, Ins1, Glis3, Nlrp5, Dsc1, Tlx 1 and Reln were preferentially expressed in lower 
Table 1 Overview of genes differentially expressed between lower (mandibular) incisor and molar

\begin{tabular}{|c|c|c|c|c|c|c|}
\hline A & Genes & Fold change & P-value & Known in teeth & Known as differentially expressed & References \\
\hline \multirow{10}{*}{ Enriched in molars } & Barx1 & 8.60 & 3.47E-09 & Yes & Yes & [42] \\
\hline & Clatnf3 & 7.30 & 4.37E-08 & No & No & \\
\hline & Adcy8 & 5.75 & $2.76 \mathrm{E}-08$ & No & No & \\
\hline & Cntn6 & 4.91 & $2.94 \mathrm{E}-07$ & No & No & \\
\hline & $\operatorname{six} 2$ & 4.82 & 4.84E-08 & Yes & Yes & [43] \\
\hline & Tcfap2b & 4.31 & $1.88 \mathrm{E}-05$ & No & No & \\
\hline & Odz1 & 4.24 & 5.02E-09 & No & No & \\
\hline & Vstm2a & 4.09 & $7.28 \mathrm{E}-08$ & No & No & \\
\hline & Nptx1 & 4.06 & $1.21 \mathrm{E}-05$ & No & No & \\
\hline & Has2 & 3.94 & $1.66 \mathrm{E}-09$ & No & No & \\
\hline \multirow{10}{*}{ Enriched in incisors } & $\operatorname{lr} \times 4$ & -5.31 & $1.92 \mathrm{E}-07$ & No & No & \\
\hline & Cacna2d3 & -5.66 & $2.55 \mathrm{E}-08$ & No & No & \\
\hline & Mcpt2 & -6.39 & $2.90 \mathrm{E}-08$ & No & No & \\
\hline & $|s| 1$ & -6.44 & $3.53 \mathrm{E}-08$ & Yes & Yes & [29] \\
\hline & Alx3 & -8.36 & $6.59 \mathrm{E}-12$ & No & No & \\
\hline & Pax3 & -11.72 & $1.68 \mathrm{E}-13$ & Yes & No & {$[45]$} \\
\hline & Sfrp4 & -12.38 & $9.88 \mathrm{E}-10$ & No & No & \\
\hline & Hand2 & -13.20 & $6.89 \mathrm{E}-14$ & Yes & Yes & [44] \\
\hline & $A / x 1$ & -15.95 & $1.35 \mathrm{E}-10$ & No & No & \\
\hline & Hpse2 & -27.41 & $2.23 \mathrm{E}-11$ & No & No & \\
\hline \multicolumn{7}{|l|}{ B } \\
\hline \multirow{13}{*}{ Enriched in molars } & Lhx6 & 3.69 & $8.95 \mathrm{E}-08$ & Yes & Yes & {$[46]$} \\
\hline & Sfrp1 & 3.56 & 7.94E-06 & Yes & No & {$[47]$} \\
\hline & Smoc2 & 3.28 & $3.28 \mathrm{E}-08$ & Yes & Yes & [41] \\
\hline & Shox2 & 2.85 & $1.08 \mathrm{E}-08$ & Yes & No & [48] \\
\hline & $D / x 1$ & 2.81 & 4.49E-11 & Yes & Yes & {$[17]$} \\
\hline & Fgf12 & 2.22 & $3.32 \mathrm{E}-06$ & Yes & No & [49] \\
\hline & Sfrp2 & 2.16 & 4.40E-11 & No & No & \\
\hline & Dbx2 & 1.97 & 8.51E-06 & Yes & No & {$[50]$} \\
\hline & Six4 & 1.95 & $8.05 \mathrm{E}-07$ & Yes & Yes & [43] \\
\hline & Six 1 & 1.83 & 8.69E-06 & Yes & Yes & [43] \\
\hline & $\operatorname{Lhx} \times$ & 1.64 & $2.87 \mathrm{E}-06$ & Yes & No & [51] \\
\hline & Bmpria & 1.36 & $7.12 \mathrm{E}-07$ & Yes & No & {$[52]$} \\
\hline & Mapk1 & 1.30 & $3.20 \mathrm{E}-06$ & Yes & No & [53] \\
\hline \multirow{12}{*}{ Enriched in incisors } & Gas1 & -1.25 & $6.93 \mathrm{E}-06$ & Yes & No & {$[54]$} \\
\hline & Hoxa2 & -1.41 & $9.43 \mathrm{E}-07$ & Yes & No & [26] \\
\hline & $T / \times 2$ & -1.47 & $7.35 \mathrm{E}-07$ & No & No & \\
\hline & $\operatorname{Ir} \times 6$ & -1.58 & 3.09E-08 & No & No & \\
\hline & Gdf6 & -2.00 & 4.01E-06 & Yes & No & {$[55]$} \\
\hline & Aqp 1 & -2.16 & $9.51 \mathrm{E}-08$ & Yes & No & {$[56]$} \\
\hline & Amtn & -2.28 & $1.65 \mathrm{E}-08$ & Yes & Yes & {$[57]$} \\
\hline & Prtg & -2.3 & $9.93 \mathrm{E}-07$ & Yes & No & [58] \\
\hline & Slitrk6 & -2.37 & $2.60 \mathrm{E}-07$ & Yes & No & {$[59]$} \\
\hline & Wnt5a & -2.38 & $1.38 \mathrm{E}-05$ & Yes & No & {$[60]$} \\
\hline & Hand1 & -2.55 & 4.01E-06 & Yes & Yes & [28] \\
\hline & Prkca & -2.75 & 7.17E-07 & Yes & No & [61] \\
\hline
\end{tabular}


Table 1 Overview of genes differentially expressed between lower (mandibular) incisor and molar (Continued)

\begin{tabular}{lllllll}
\hline T/x1 & -2.84 & $6.05 \mathrm{E}-08$ & Yes & No & [62] \\
\hline Bmp5 & -3.20 & $3.00 \mathrm{E}-08$ & No & No & \\
\hline Cyp26c1 & -4.05 & $3.10 \mathrm{E}-09$ & Yes & No & [63] \\
\hline Nts & -4.43 & $9.56 \mathrm{E}-10$ & Yes & No & No \\
\hline Irx4 & -5.31 & $1.92 \mathrm{E}-07$ & No & [64] \\
\hline
\end{tabular}

The table is subdivided in two sections highlighting: (A) The "top ten" genes showing the highest degree of enrichment in incisor (negative values) or molar (positive values); (B) additional examples of differentially expressed genes, some already known from the literature as being expressed in developing teeth, others not predicted from the literature. Separate columns indicate those genes already known as being expressed in developing teeth ("Known in teeth"), and sometimes as being differentially expressed in both tooth types ("Known as differentially expressed"). In all cases, one relevant reference has been selected. For a complete list of differentially expressed genes (with fold changes $>2$ or $<-2$ ), see Additional file 2 .

incisors. Hand1 and Hand2 were also preferentially expressed in the incisor area, as previously reported at E10.5 [44].

Relevant networks when considering genes from selected pathways or families From the 107 differentially expressed genes in the selected pathways, 50 genes were mapped in only 4 different networks involved in embryonic or tissue development (Additional file 3). The first network (score=24) contained 16 differentially expressed genes and was focused on Six1, a gene highly expressed in molars. This network contained two additional Six genes, Six 2 and Six4, also more expressed in molars, as well as Six5, which was not differentially expressed. It further contained Irx4 and 6, preferentially expressed in incisors, whereas Irx2 was not differentially expressed. In this network we also found $D l x 1$, a gene preferentially expressed in molars, whereas $D l x 2$ and $D l x 5$ were not differentially expressed. $H m x 2$, Arx, Gsx2, Crx and Wnt11 were more expressed in incisors. Some Hox genes appeared in this network. Hox genes were classically considered as being not expressed in the maxillo-mandibular region, which derives from the first embryonic branchial arch [26], but recent expression studies have revealed expression of some Hox genes in specific developing tooth compartments [27]. This network also contained genes known to act during tooth development, like Bmp4 or Fgf10, but these were not differentially expressed.

The second network (score=20) contained 14 differentially expressed genes and was centered on Shox2, a homeobox gene known to be expressed in teeth at E14.5 (Additional file 3). Only this gene and Sfrp2 were more expressed in molars in this network. All others genes like Tlx2, Brtc, Cer1, Hhex, or $\operatorname{Lmx} 1 b$, were preferentially expressed in incisors. This nework also contained genes known to be involved in odontogenesis, like Runx2 and Pitx2, and which were not differentially expressed. The third network was centered on Pparg (encoding PPAR $\gamma$, a member of the nuclear receptor superfamily) and all molecules from this network were more highly expressed in incisors except one nuclear receptor gene, Nr2f2 (encoding COUP-TFII). The fourth network was centered on fos and contained several genes from the retinoic acid pathway preferentially expressed in incisors (Additional file 3).

\section{Expression profiling of lower versus upper molars Genes with a fold change higher than 2}

We found 96 genes differentially expressed between mandibular and maxillary molars with a fold change higher than 2 (Table 3; Additional file 4 for a full list). The gene with highest expression in maxillary molars was $C y p 26 c 1$, a gene previously shown to be expressed in teeth [63] and found to be also differentially expressed between molars and incisors in our microarray analysis. The Nefl gene, responsible for Charcot Marie Tooth disease, was the most highly enriched in mandibular molars (Table 3A). Nkx2-3 had already been reported in the literature as differentially expressed between the two tooth types [69] (Table 3A). Examination of $N k x 2-3$ null mice revealed defects in maturation and cellular organization of the sublingual glands. Furthermore, cusps were absent from mandibular molars and the third molar was occasionally missing [69].

Other genes previously described as acting during odontogenesis were identified as being differentially expressed in our microarray analysis. Seven of them were expressed with a fold change higher than 2 (Table 3B). Among these, Pitx 1 had already been described as being differentially expressed between upper and lower molars [19]. Inactivation of the Pitx 1 gene in mice affected mandibular tooth morphogenesis [19].

Among the "new" genes unravelled by our microarray analysis, several belong to gene families with other members known to act during odontogenesis. $L h x 1$ and Lhx 9 were identified as displaying enriched expression in mandibular molars (Table 3B). Their paralogues $L h x 6$ and $L h x 7$ are implicated in tooth patterning at E10.5 [46]. $L h x 6 / 7$ double mutant embryos lacked molar teeth. Despite molar agenesis, $L h \times 6 / 7$-deficient animals had normal incisors which, in the maxilla, were flanked by a supernumerary pair of incisor-like teeth [74]. $N k x 6-1$ and $N k x 2-1$ appeared interesting as their paralogue $N k x 2-3$ is already known to be differentially expressed between mandibular and maxillary molars [69]. Msx3 was 
Table 2 Overview of genes belonging to selected signaling pathways (FGF, TGF $\beta$ /BMP, Wnt, Hedgehog, Retinoic acid, Notch) or to the homeobox-containing superfamily, showing differential expression in mandibular molar or incisor

\begin{tabular}{|c|c|c|c|c|c|c|}
\hline Pathway/Family & Gene names (fold change) & $\begin{array}{l}\text { Number of } \\
\text { genes }\end{array}$ & $\begin{array}{l}\text { Differentially } \\
\text { expressed in teeth }\end{array}$ & $\begin{array}{l}\text { Not known to be } \\
\text { differentially expressed } \\
\text { in teeth }\end{array}$ & $\begin{array}{l}\text { New genes } \\
\text { in teeth }\end{array}$ & $\begin{array}{l}\text { Total new genes and } \\
\text { new differentially } \\
\text { expressed genes }\end{array}$ \\
\hline FGF: molars & Fgf12 (2.24) & 1 & 0 & 1 & 0 & 1 \\
\hline FGF: incisors & Fgf22 (-1.41) & 1 & 0 & 0 & 1 & 1 \\
\hline TGF $\beta$ : molars & Thbs2 (1.77); Gdf7 (1.73); $\frac{\text { Bmpr1a (1.36); Ppp2r1b (1.35); Mapk1 (1.3); Smurf2 }}{(1.25)}$ & 6 & 0 & 2 & 4 & 6 \\
\hline TGF $\beta$ : incisors & Bmp5 (-3.20); Gdf6 (-2.00); Acvr1c (-1.59); Inhbe (-1.52); Nodal (-1.45) & 5 & 0 & 1 & 4 & 5 \\
\hline Wnt: molars & $\begin{array}{c}\text { Sfrp1 (3.56); Sfrp2 (2.16); PIcb4 (1.66); Camk2d (1.48); Ccnd2 (1.44); Ppp2r1b (1.35); } \\
\text { Cul1 (1.30); Ppp3cb }\end{array}$ & 8 & 0 & 1 & 7 & 8 \\
\hline Wnt: incisors & Sfrp4 (-12.38); $\frac{\text { Wnt 5a (-2.38); Cer1 (-1.64); Wnt9b (-1.51); Wnt1 (-1.45); }}{\operatorname{Camk2a(-1.34);Ppp3r2~(-1.32)~}}$ & 7 & 0 & 1 & 6 & 7 \\
\hline $\begin{array}{l}\text { Hedgehog } \\
\text { incisors }\end{array}$ & Ihh (-1.30); Btrc (1.26); Gas1 -(1.25) & 3 & 0 & 1 & 2 & 3 \\
\hline $\begin{array}{l}\text { Retinoic acid: } \\
\text { molars }\end{array}$ & Cyp1b1; Nr2f1 (3.59); Nr2f2 (2.69). Aldh7a1 (1.50) & 4 & 0 & 0 & 4 & 4 \\
\hline $\begin{array}{l}\text { Retinoic acid: } \\
\text { incisors }\end{array}$ & $\begin{array}{c}\text { Cyp26c1 (-4.05); Cyp2c54 (-2.26); Rdh1 (-1.94); Cyp2c66 (-1.81); Cyp2a12 } \\
\text { (-1.76); Rarres1 (-1.57); Rdh9 (-1.57); Ugt1a9 (-1.57); Aldh1b1 (-1.51); Rbp3 } \\
\text { (-1.49); Pram1 (-1.43); Rarres2 (-1.35); Adh7 (-1.33); Cyp2b19 (-1.31); Rdh8 (-1.29) }\end{array}$ & 15 & 0 & 1 & 14 & 15 \\
\hline Notch: incisors & Rbpjkl (-2.12); predicted gene 5109 (-1.71); DII1 (-1.37) & 3 & 0 & 0 & 3 & 3 \\
\hline $\begin{array}{l}\text { Homeobox } \\
\text { genes: molars }\end{array}$ & 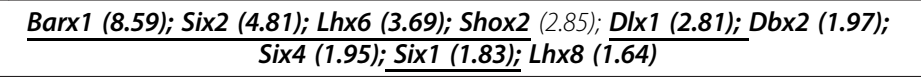 & 9 & 6 & 2 & 1 & 3 \\
\hline $\begin{array}{l}\text { Homeobox } \\
\text { genes: incisors }\end{array}$ & $\begin{array}{l}\text { Alx1 (-15.94) Alx3 (-8.36); IsI1 (-6.44); Irx4 (-5.31); TIx1 (-2.83); Otx1 (-2.48); } \\
\text { Hoxa11 (-1.92); Hoxd8 (-1.86); Hoxd3 (-1.84); Hoxd4 }(-1.81) ; \text { Obox5 (-1.76); Lbx2 } \\
\text { (-1.74); Rhox6 (-1.72); Hoxd10 (-1.66); Rhox1 (-1.62); Lmx1b (-1.61); Hoxd11 } \\
\text { (-1.60); Hoxd1 (-1.60); Nkx2-1 (-1.60);Hnf1b (-1.59); Hoxc6 (-1.58); Irx6 (-1.58); } \\
\text { Sebox (-1.57); Hhex (-1.55); Lhx4 (-1.54); Rhox12 (-1.54); Rhox2a (-1.53); Hoxc4 } \\
\text { (-1.52); TIx2 (-1.47); Rhox7 (-1.46); Hoxa9 (-1.44); Hoxa2 (-1.41); Pdx1 (-1.40); } \\
\text { Hoxb9 (-1.40); Esx1 (-1.39); Crx (-1.36); Hoxb7 (-1.36); Hoxa6 (-1.35); Arx (-1.33); } \\
\text { Dux (-1.33); Lbxcor1 (-1.32); Gsx2 (-1.29); Hmx2 (-1.27); Hoxb2 (-1.27); Gbx1 } \\
(-1.26)\end{array}$ & 45 & 2 & 1 & 42 & 43 \\
\hline
\end{tabular}

Genes are listed as being enriched in expression in molar or incisor, with fold changes in expression in parentheses. Genes already known from the literature to be expressed in teeth appear in bold, and those for which a differential expression was reported for the two tooth types are underlined. Additional columns summarize the literature survey, scoring genes previously described as expressed in developing teeth ("Known in teeth"), as differentially expressed in both tooth types ("Known as differentially expressed"), or "new" (i.e. not described in the literature: right-most column). 


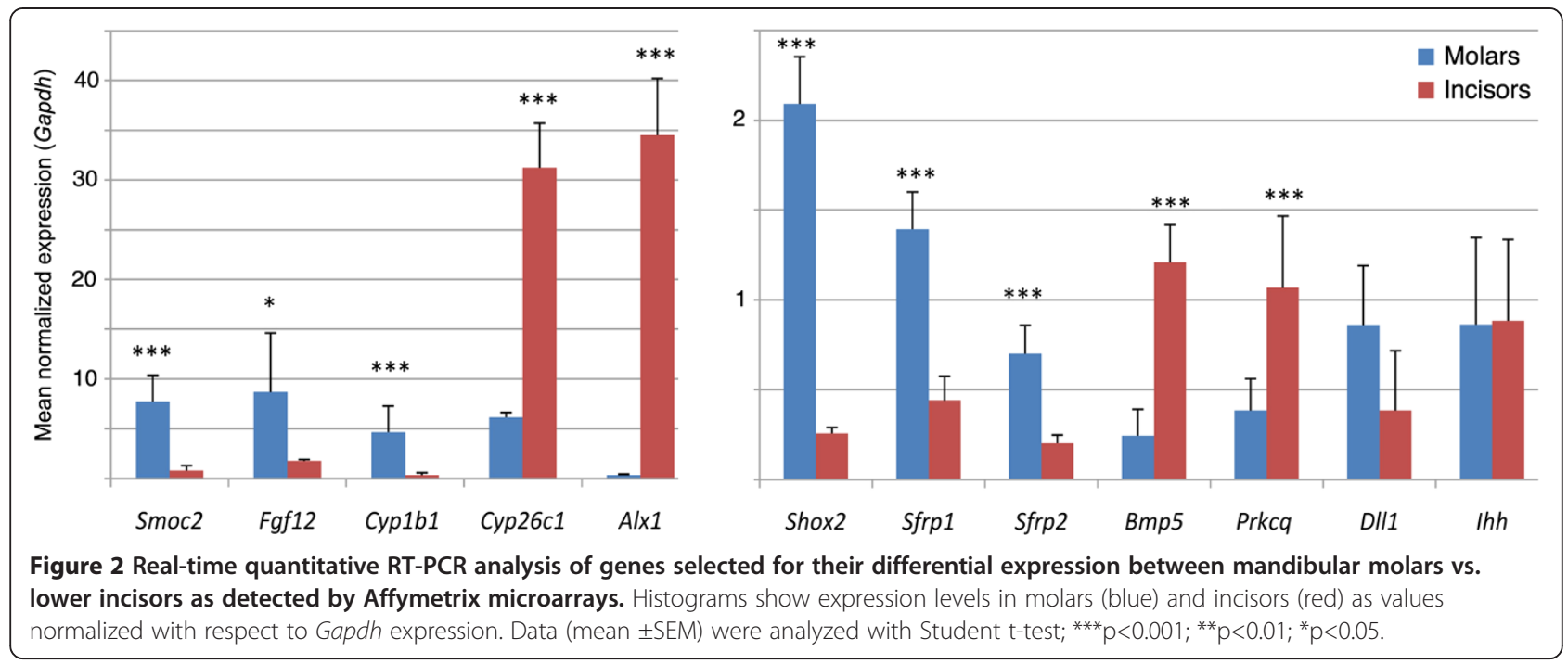

identified as being enriched in mandibular molars; its homologues Msx 1 and $M s x 2$ are known to play a role in mouse dentition patterning at E10.5 [75]. Alx1, which was differentially expressed in mandibular molars vs. incisors in our microarray analysis, was also found to be expressed at higher levels in maxillary molars (Table 3A).

\section{Genes from selected pathways or families}

Among the 2070 genes with a fold change higher than 1.2 and a p-value lower than 0.1 in mandibular vs. maxillary molars, 61 belonged to the pathways or families selected for further analysis (Table 4). Only nine genes were known to be expressed in teeth (Table 4, in bold),

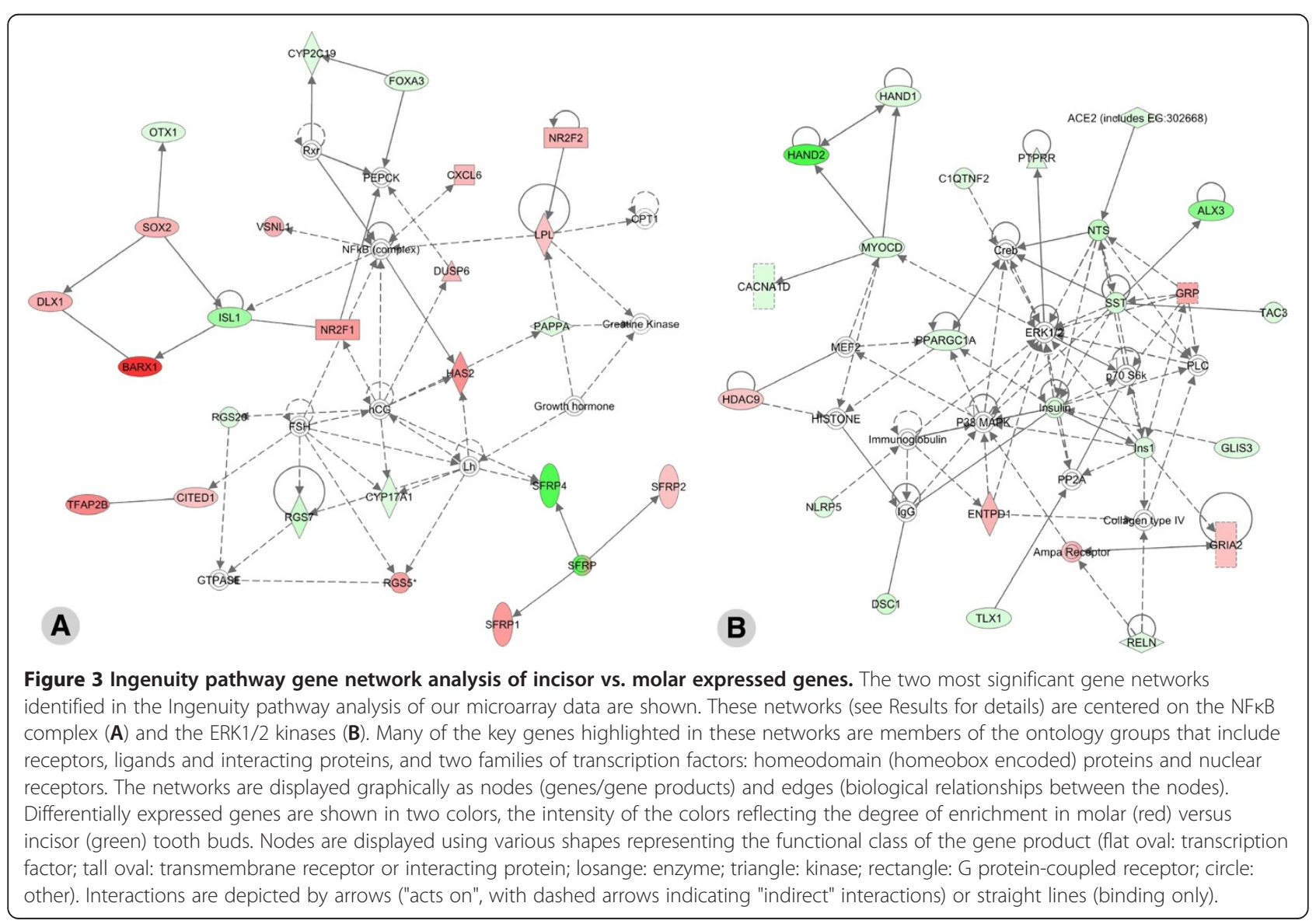


Table 3 Overview of genes differentially expressed between lower (mandibular) and upper (maxillary) molars

\begin{tabular}{|c|c|c|c|c|c|c|}
\hline A & Genes & Fold change & P-value & Known in teeth & Known as differentially expressed & References \\
\hline \multirow{10}{*}{ Enriched in lower molars } & Nefl & 6.28 & $1.68 \mathrm{E}-08$ & No & No & \\
\hline & Ostn & 4.12 & $6.22 \mathrm{E}-06$ & No & No & \\
\hline & $N k \times 2-3$ & 3.97 & $5.32 \mathrm{E}-10$ & Yes & Yes & [69] \\
\hline & Tnnt1 & 3.19 & $9.08 \mathrm{E}-08$ & No & No & \\
\hline & Chrnal & 3.04 & 4.47E-06 & No & No & \\
\hline & Nefm & 3.01 & $1.54 \mathrm{E}-08$ & No & No & \\
\hline & Myf5 & 2.94 & 7.14E-09 & No & No & \\
\hline & KIh/31 & 2.92 & $4.58 \mathrm{E}-08$ & No & No & \\
\hline & Plac8 & 2.91 & $4.68 \mathrm{E}-09$ & No & No & \\
\hline & Synpo21 & 2.87 & $3.71 \mathrm{E}-08$ & No & No & \\
\hline \multirow{10}{*}{ Enriched in upper molars } & Naalad2 & -2.21 & $6.48 \mathrm{E}-09$ & No & No & \\
\hline & Kcnb2 & -2.29 & $1.42 \mathrm{E}-06$ & No & No & \\
\hline & $\operatorname{ltg} a 8$ & -2.34 & 4.57E-08 & No & No & \\
\hline & Atp6 & -2.84 & $1.26 \mathrm{E}-07$ & No & No & \\
\hline & $A \mid x 1$ & -2.85 & $2.50 \mathrm{E}-08$ & No & No & \\
\hline & Gabrb2 & -3.06 & $7.32 \mathrm{E}-09$ & No & No & \\
\hline & Ndst4 & -3.48 & $4.21 \mathrm{E}-06$ & No & No & \\
\hline & Pla2g7 & -3.99 & $1.34 \mathrm{E}-08$ & No & No & \\
\hline & $\mathrm{Nmbr}$ & -4.25 & $5.52 \mathrm{E}-10$ & No & No & \\
\hline & Cyp26c1 & -5.04 & $1.74 \mathrm{E}-10$ & Yes & No & {$[63]$} \\
\hline B & & & & & & \\
\hline \multirow{10}{*}{ Enriched in lower molars } & $D / x 6$ & 2.76 & $1.01 \mathrm{E}-07$ & Yes & No & [70] \\
\hline & GsC & 2.21 & $1.31 \mathrm{E}-06$ & Yes & No & [71] \\
\hline & Pitx1 & 2.19 & $6.09 \mathrm{E}-08$ & Yes & Yes & {$[19]$} \\
\hline & Prkca & 2.15 & $6.71 \mathrm{E}-07$ & Yes & No & {$[61]$} \\
\hline & Barx2 & 2.00 & 3.47E-07 & Yes & No & [72] \\
\hline & Lhx9 & 1.86 & $1.12 \mathrm{E}-06$ & No & No & \\
\hline & $N k \times 6-1$ & 1.62 & 4.43E-08 & No & No & \\
\hline & Lhxl & 1.48 & $2.87 \mathrm{E}-06$ & No & No & \\
\hline & Msx3 & 1.43 & $8.33 \mathrm{E}-07$ & No & No & \\
\hline & $N k \times 2-1$ & 1.40 & $1.84 \mathrm{E}-06$ & No & No & \\
\hline \multirow{3}{*}{ Enriched in upper molars } & Gli1 & -1.34 & $6.21 \mathrm{E}-07$ & Yes & No & [73] \\
\hline & $D / x 1$ & -1.36 & $2.18 \mathrm{E}-06$ & Yes & No & [71] \\
\hline & $\operatorname{Lhx} \times$ & -1.48 & $2.57 \mathrm{E}-06$ & Yes & No & {$[51]$} \\
\hline
\end{tabular}

As for Table 1, this table is organized in two sections showing: (A) The top ten genes showing highest expression in mandibular (lower) molars (positive values) or maxillary (upper) molars (negative values); (B) examples of genes known from the literature as being expressed in developing teeth, only a minority being described as differentially expressed in upper vs. lower molars ("Known as differentially expressed"), or not described in the literature. Among the top ten genes, only two were known to be expressed in developing teeth. For a complete list of differentially expressed genes (with fold changes $>2$ or $<-2$ ), see Additional file 4 .

four of these being reported to be differentially expressed betwen the two tooth types (Table 4, underlined). Fiftythree genes had not yet been described as being expressed or acting during odontogenesis. In total we found 58 new genes not known to be differentially expressed between the two tooth types.

\section{Quantitative RT-PCR analysis}

To further validate our microarray experiments, a subset of 10 genes were selected for quantitative RT-PCR analysis. We focused our analysis on genes encoding known signaling molecules or their effectors: Wnt11, the FGF receptor gene Fgfr4, Gli1 (an effector of the Hedgehog pathway), and Dll1 (Delta-like 1) acting in the Notch pathway. We also chose the Rorb and Cyp26c1 genes from the retinoic acid signaling pathway, and Alx 1 as a homeobox gene. We further decided to analyze one of the integrin genes (Itga8) identified as being differentially expressed, Prkcq (which was also found as differentially expressed between incisor and molar; see above), 
Table 4 Overview of genes belonging to selected signaling pathways (FGF, TGF $\beta$ /BMP, Wnt, Hedgehog, Retinoic acid, Notch) or to the homeobox gene superfamily, showing differential expression in mandibular (inferior) versus maxillary (superior) molars

\begin{tabular}{|c|c|c|c|c|c|c|}
\hline Pathway/Family & Gene names (fold change) & $\begin{array}{l}\text { Number of } \\
\text { genes }\end{array}$ & $\begin{array}{c}\text { Differentially } \\
\text { expressed in teeth }\end{array}$ & $\begin{array}{l}\text { Not known to be } \\
\text { differentially } \\
\text { expressed in teeth }\end{array}$ & $\begin{array}{c}\mathrm{New} \\
\text { genes in teeth }\end{array}$ & $\begin{array}{l}\text { Total new genes an } \\
\text { new differentially } \\
\text { expressed genes }\end{array}$ \\
\hline
\end{tabular}

\begin{tabular}{|c|c|c|c|c|c|c|}
\hline & & & \multicolumn{3}{|c|}{ expressed in teeth } & expressed genes \\
\hline FGF: lower molars & Fgfr4 (2.58); Fgf16 (1.86) & 2 & 0 & 0 & 2 & 2 \\
\hline TGFß: lower molars & Amhr2 (1.68); Acvr2b (1.26) & 2 & 0 & 1 & 1 & 2 \\
\hline TGF $\beta$ : upper molars & Smad9 $(-1.53)$ & 1 & 0 & 0 & 1 & 1 \\
\hline Wnt: lower molars & $\begin{array}{c}\text { Camk2a (1.83); Fzd8 (1.67); Wnt9b (1.55); Camk2b (1.50); Wnt11 } \\
\text { (1.39); Plcb2(1.39); Fzd5 (1.29); Cer1 (1.26) }\end{array}$ & 8 & 0 & 0 & 8 & 8 \\
\hline Wnt: upper molars & Vangl1 (-1.22) & 1 & 0 & 0 & 1 & 1 \\
\hline Hedgehog: upper molars & $\underline{\text { Gli1 }(-1.34)}$ & 1 & 1 & 0 & 0 & 0 \\
\hline Retinoic acid: lower molars & Rorb (2.09); Rbp2 (1.59); Crabp2 (1.58); Polr2l (1.37);Rdh8 (1.27) & 5 & 0 & 0 & 5 & 5 \\
\hline Retinoic acid: upper molars & Cyp26c1 (-5.04); Aldh1a1 (-1.98); Dhrs3 (-1.51) & 3 & 0 & 1 & 2 & 3 \\
\hline Notch: lower molars & Dtx4 (1.81); DII1 (1.41); Rfng (1.31); D//3 (1.36) & 4 & 0 & 0 & 4 & 4 \\
\hline Homeobox genes: lower molars & 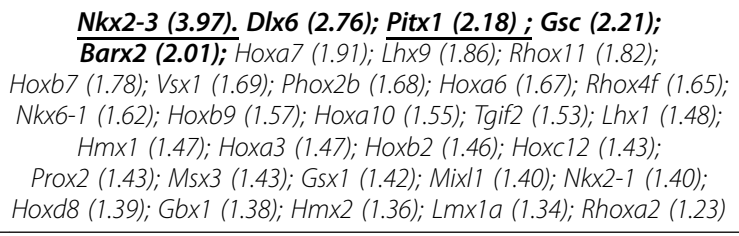 & 32 & 3 & 2 & 27 & 29 \\
\hline Homeobox genes: upper molars & Alx1 (-2.85); Lhx8 (-1.48); DIx1 (-1.36) & 3 & 1 & 1 & 1 & 2 \\
\hline Total & & 62 & 4 & 5 & 53 & 58 \\
\hline
\end{tabular}

Fold changes in expression are indicated in parentheses. As in Table 2, genes known from the literature to be expressed in teeth appear in bold, and those for which a differential expression was reported are underlined. Additional columns scoring the genes previously described as being expressed in developing teeth ("Known in teeth"), as being differentially expressed in both molar types ("Known as differentially expressed"), or "new" (not previously described). 
and Adamtsl3. Among the ten genes analyzed by qRTPCR, eight were confirmed to be differentially expressed as detected by microarray analysis (Figure 4), whereas two (Gli1 and Wnt11) were not found to be differentially expressed.

\section{Gene network analysis}

Relevant networks when considering all genes with a fold change higher than 2 Among the 96 genes with a fold change higher than 2, 36 genes were mapped in two networks. The first network (score=27) was centered on ERK1/2 and included 13 genes identified as being differentially expressed between the two molar types (Figure 5A). Chnrq, Chnra1, Acp1, Angtpl1, Plac8, Fgfr4, Il1r1, Grap2, Cftr, Prkcq, Ankrd1 and Mypn were more highly expressed in mandibular molars, whereas Pla2g7 was enriched in maxillary molars. The second network (score $=25$ ) was centered on tretinoin (a retinoic acid derivative, used as a medication for skin diseases) and contained 12 differentially expressed genes (Figure 5B). Rorb and Pla2g7 were the only two genes more expressed in maxillary molars, whereas Pitx1, Tbx4, Gsc, Nkx2-3, Corin, Barx2, Otx1, Dlx6, Gjb2 and Pgfr4 were more expressed in mandibular molars.

Relevant networks when considering genes from selected pathways or families From the 62 differentially expressed genes belonging to the pathways selected for analysis, 23 genes were mapped in only 2 different networks involved in embryonic or tissue development (Additional file 5). The first network contained 11 differentially expressed molecules and was centered on $D l x 1$ (a gene known to be expressed in the presumptive molar region at E10.5 [17]. Dlx1 and Itga8 were the only two genes identified as being more highly expressed in maxillary molars, whereas Nkx6-1, Phox 2b, Gsx1, Rhox4b were found to be enriched in mandibular molars. The second network contained 12 differentially expressed genes and was focused on Gli3. Only Aldh1a1 was more expressed in maxillary molars, whereas Barx2, Nkx3-2, Nkx2-1, Cer1, Lhx1, Gsc, Camk2b, Camk2a, Hmx2 and Dll1 were preferentially expressed in mandibular molars.

\section{Conclusions}

This study provides the first comprehensive analysis of differential gene expression between developing murine tooth types, leading to new insights into the regulatory mechanisms involved in the ontogenesis of mammalian teeth. Molecules belonging to pathways involved in various aspects of development (such as the Wnt, TGF $\beta$ / BMP, or FGF pathways) were discovered as potentially carrying information for differential tooth morphogenesis. Of interest is the involvement of the retinoic acid pathway [76], as retinoids have marked effects on molar and incisor morphogenesis [22,77]. Tooth morphology and its evolution in various mammalian species were proven to be related to dosage effect of signaling molecules, like for instance FGF3 being able to modify the cusps pattern [16,78]. Our microarray analysis highlighted molecules more or less strongly expressed in a given tooth type, reinforcing the model of dosage modulating mechanisms. Gene dosage abnormalities are likely to occur in human rare diseases presenting with a tooth family specific dental phenotype [37,38,79]. Some of the corresponding genes were not retrieved in our analysis of differential gene expression in lower incisors versus lower or upper molars, suggesting that other levels of regulation, post-transcriptionally via effectors of a given pathway or via fine tuning of kinase signaling (e.g. ref. [80]), will undoubtedly also participate in the molecular identity leading to specific tooth morphology. Future investigation of differential gene expressions
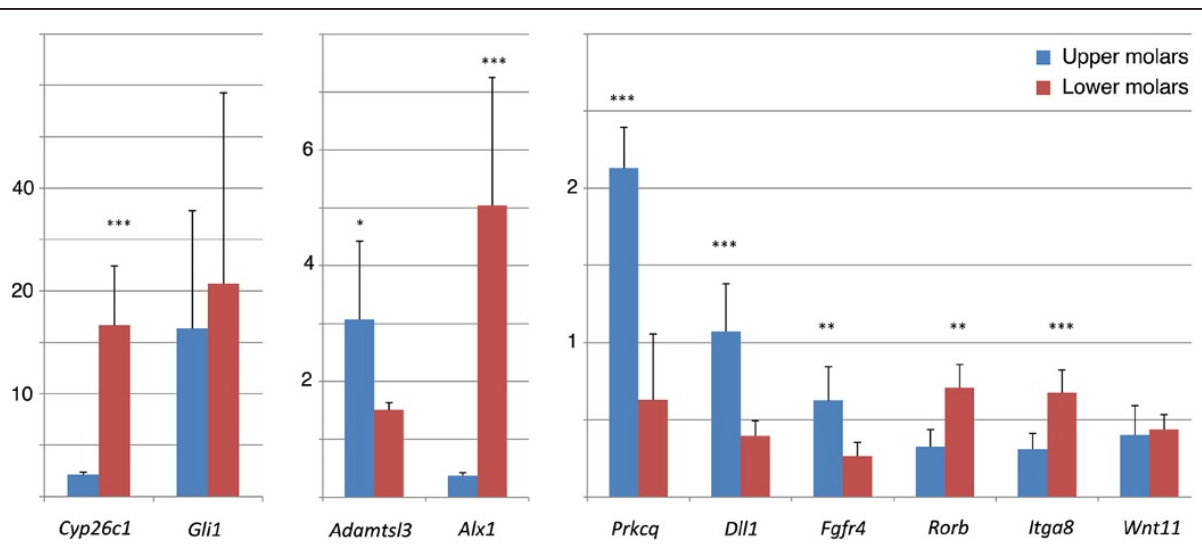

Figure 4 Real-time quantitative RT-PCR analysis of genes selected for their differential expression between mandibular vs. maxillary molars as detected by Affymetrix microarrays. Histograms show expression levels in mandibular molars (gray) and maxillary molars (black), with values normalized with respect to Gapdh expression. Data (mean \pm SEM) were analyzed with Student t-test; ${ }^{* * *} p<0.001$; ${ }^{* *} \mathrm{p}<0.01 ;{ }^{*} \mathrm{p}<0.05$. 


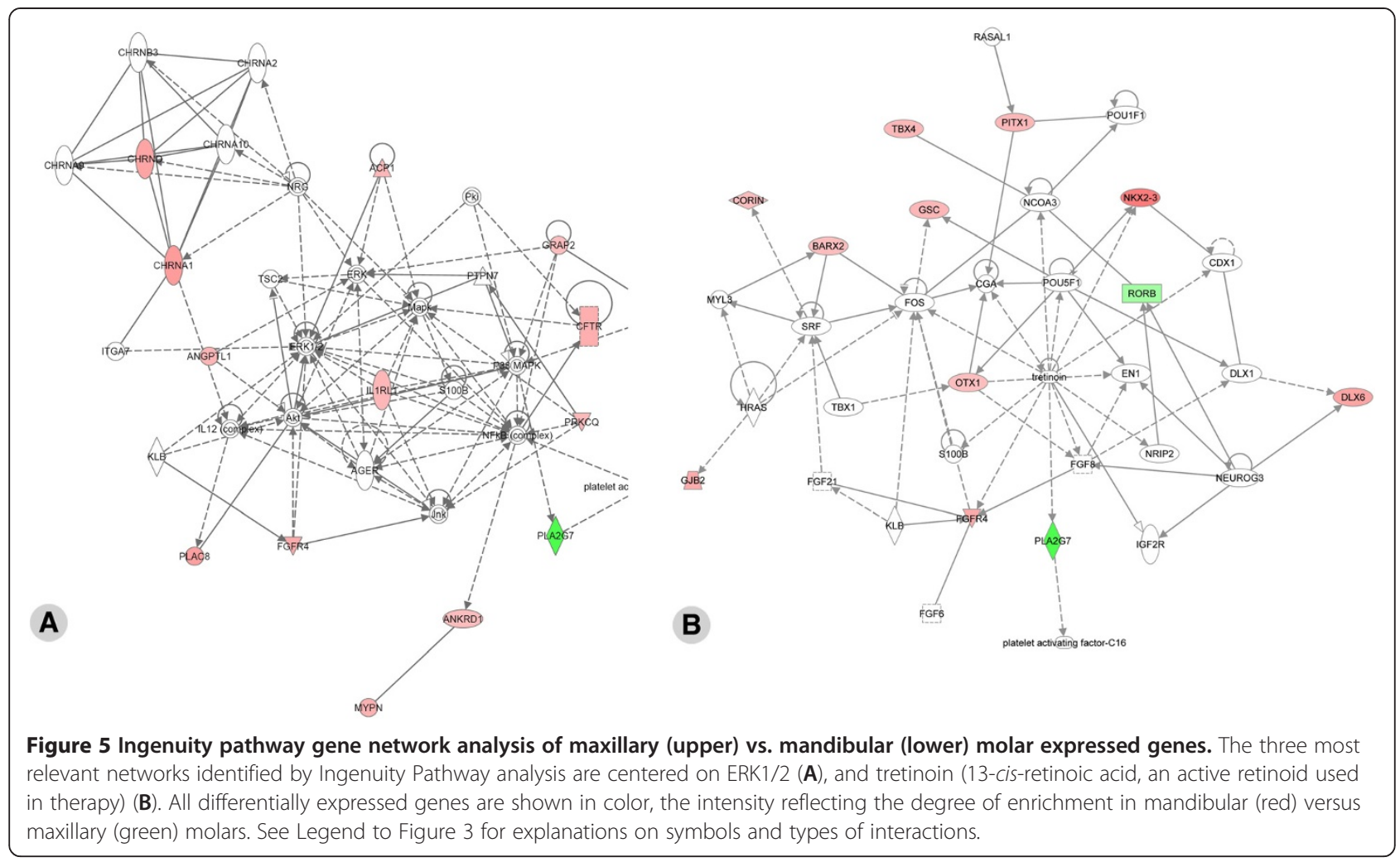

between upper and lower incisors, two similar tooth types formed from neural crest cells of different origins, might also contribute to shed light on specific morphogenesis and its link to individual tooth shape.

\section{Methods}

\section{Tissue collection}

Pregnant C57BL6 female mice were euthanized at 14.5 days of gestation (E14.5), embryos were collected and tooth samples (lower incisors, mandibular and maxillary first molars) were microdissected. Tissue samples were frozen in liquid nitrogen and kept at $-80^{\circ} \mathrm{C}$ until use. The CERBM-GIE/ICS/IGBMC complies with the French national and European laws and regulations relating to the transport, housing and use of animals in research.

\section{Microarray hybridization}

Total RNA was extracted with the RNAeasy micro Kit (Qiagen) from pools of 4 tooth germs to obtain enough RNA for subsequent microarray hybridization. RNA quality was verified by analysis on a 2100 Bioanalyzer (Agilent). All samples displayed a RNA Integrity Number (RIN) greater than 9.8. Biotinylated single strand cDNA targets were prepared, starting from 300 ng of total RNA, using the Ambion WT Expression Kit (Cat \#4411974) and the Affymetrix GeneChip WT Terminal Labeling Kit (Cat \#900671), according to Affymetrix recommendations.
Four lower incisors samples, 4 maxillary molars samples and 8 mandibular molars samples were hybridized on Affymetrix GeneChip Mouse Gene 1.0 ST arrays. Briefly, following fragmentation and end-labeling, $1.9 \mu \mathrm{g}$ cDNA was hybridized for $16 \mathrm{~h}$ at $45^{\circ} \mathrm{C}$ on the arrays interrogating 28,853 genes represented by approximately 27 probes spread across the full length of the gene. The chips were washed and stained in the GeneChip Fluidics Station 450 (Affymetrix), and scanned with the GeneChip Scanner 3000 7G (Affymetrix). Finally, raw data (.CEL Intensity files) were extracted from the scanned images using the Affymetrix GeneChip Command Console (AGCC) version 3.1. One incisor sample was excluded from the analysis because a technical problem occured during hybridization washing.

\section{Microarray analysis}

CEL files were further processed with the Partek software to obtain principal component analysis (PCA) and to select only genes with a signal value above 5 (20th percentile of all expression values) in at least one sample. The analysis was done only on three lower incisors samples as a technical problem during hybridization occurred for one of the 4 samples (high background). Genes were considered as differentially expressed if the false discovery rate from Benjamini and Hochberg test was under 0.1. 


\section{Ingenuity pathways analysis}

Biologically relevant networks were created using the Ingenuity Pathway Analysis software (http://www.Ingenuity. com). Based on the algorithmically generated connectivity between gene-gene, gene-protein, and protein-protein interactions, the program develops functional molecular networks that overlay genes in the dataset. This program calculated p-values for each network by comparing the number of genes that were mapped in a given network, relative to the total number of occurrences of those genes in all networks. The score for each network is given as the negative log of the p-value, which indicates the likelihood of finding a set of genes in the network by random chance. For instance, a score of 20 indicates that there is a $10^{-20}$ chance that the genes in focus would be in a network because of random chance. Networks taking in account direct and indirect interactions have been generated for genes with a fold change higher than 2, whereas networks involving only direct interactions have been created for genes that were selected as members of pathways or families of interest with a fold change higher than 1.2.

\section{Real-time quantitative RT-PCR}

RT-PCR assays were performed in duplicate on three RNA samples for each tooth type, distinct from the ones used for microarray hybridization. RNA extractions were performed as previously described. Oligo-dT primed cDNAs were generated using the Superscript II kit (Invitrogen) according to the manufacturer's protocol. Quantitative real-time PCR was achieved using SybrGreen and LightCycler 480 (Roche). The sequences of primers used for the various tested genes are given in Additional file 6. A probe set for detection of mouse Gapdh (a housekeeping gene) was used for normalisation. For each sample the ratio between signals for the gene of interest and Gapdh was calculated to normalize concentration values. To verify if genes were differentially expressed in different tooth types, the average of ratios calculated for lower incisors, mandibular molars and maxillary molars were then compared.

\section{Availability of supporting data}

The data discussed in this publication have been deposited in NCBI's Gene Expression Omnibus (GEO) [81] and are accessible through GEO Series accession number GSE43144. (http://www.ncbi.nlm.nih.gov/geo/query/ acc.cgi?acc $=$ GSE43144).

\section{Additional files}

Additional file 1: Principal component analysis (PCA) of mandibular molar vs. lower incisor samples (A), and mandibular vs. maxillary molar samples (B). Mandibular molar samples are represented in red, and incisor or maxillary molar samples in blue. The units are data- dependent and are generated by the software, which gives coordinates to each sample according to three axes that relate to the weight (inertia) of the decomposition into 3 principal components. For both analyses, samples segregate in two distinct groups, showing relevant transcriptional differences between the two tooth types.

Additional file 2: This table presents an overview of genes showing differential expression in developing mandibular incisors versus molars. Only the genes exhibiting at least a two fold change in expression according to Affymetrix microarray analysis are listed. Genes with the highest expression in incisors (positive values) or molars (negative values) appear on top and bottom of the list, respectively.

Additional file 3: Ingenuity pathway gene network analysis of genes belonging to selected pathways and/or superfamily (homeobox genes), showing differential expression in incisor or molar tooth buds. Four relevant networks were constructed by Ingenuity pathway analysis. The networks are displayed graphically as nodes (genes/gene products) and edges (biological relationships between the nodes). Differentially expressed genes are shown in two colors, the intensity of the colors reflecting the degree of enrichment in molar (red) versus incisor (green) tooth buds. Nodes are displayed using various shapes representing the functional class of the gene product (flat oval: transcription factor; tall oval: transmembrane receptor or interacting protein; losange: enzyme; triangle: kinase; rectangle: G protein-coupled receptor; circle: other). Interactions are depicted by arrows ("acts on", with dashed arrows indicating "indirect" interactions) or straight lines (binding only).

Additional file 4: Overview of genes showing differential expression in developing mandibular (lower) versus maxillary (upper) molars. Only the genes exhibiting at least a two fold change in expression according to Affymetrix microarray analysis are listed. Genes with the highest expression in upper molars (positive values) or lower molars (negative values) appear on top and bottom of the list, respectively.

Additional file 5: Ingenuity pathway gene network analysis of genes belonging to selected pathways and/or superfamily (homeobox genes), showing differential expression in upper versus lower molars. Two relevant networks are centered on D/X1 (network 1) and Gli3 (network 2). See Legend to Additional file 3 for key and explanations.

Additional file 6: Sequences of primers used for real-time qRT-PCR assays.

\section{Competing interests}

The authors declare that they have no competing interests.

\section{Authors' contributions}

All authors contributed to the overall experimental design. VLH and MP performed the tissue collection, RNA extraction, and real-time RT-PCR experiments. CTC did the microarray hybridization. VLH and DD performed all statistical analyses. VLH, PD and ABZ wrote the manuscript. All authors read, contributed to, and approved the final manuscript.

\section{Acknowledgments}

We thank V. Fraulob, B. Schuhbaur, and members of the IGBMC microarray core facility, for technical assistance. This work was supported by grants from the University of Strasbourg, the Hôpitaux Universitaires de Strasbourg (API, 2009-2012, "Development of the oral cavity: from gene to clinical phenotype in Human") by IFRO (Institut Français pour la Recherche Odontologique), from Offensive Sciences, a Science Initiative in the Trinational Metropolitan Region of the Upper Rhine, FEDER (European fund for regional development), Program INTERREG IV Upper Rhine, Project A27 Oro-dental manifestations of rare diseases and by institutional funds from the Centre National de la Recherche Scientifique (CNRS) and Institut National de la Santé et de la Recherche Médicale (INSERM). V.L-H. was the recipient of a PhD fellowship from the Ministère Français de la Recherche. M.P. was supported by a grant from the Fondation pour la Recherche Médicale (FRM).

\section{Author details}

${ }^{1}$ Developmental Biology and Stem Cells Department, Institut de Génétique et de Biologie Moléculaire et Cellulaire (IGBMC), Centre National de la 
Recherche Scientifique (UMR 7104), Institut National de la Santé et de la Recherche Médicale (U 964), Fédération de Médecine Translationnelle de Strasbourg (FMTS), Université de Strasbourg, BP 10142, 1 rue Laurent Fries, IIlkirch Cedex 67404, France. ${ }^{2}$ Microarray and Sequencing Platform, Institut de Génétique et de Biologie Moléculaire et Cellulaire (IGBMC), Centre National de la Recherche Scientifique (UMR 7104), Institut National de la Santé et de la Recherche Médicale (U 964), Université de Strasbourg, Illkirch-Strasbourg, France. ${ }^{3}$ University of Strasbourg, Faculty of Dentistry, 1 place de l'Hôpital, Strasbourg, France. ${ }^{4}$ Reference Centre for Orodental Manifestations of Rare Diseases, Pôle de Médecine et Chirurgie Bucco-dentaires, Hôpitaux Universitaires de Strasbourg (HUS), Strasbourg, France.

Received: 17 September 2012 Accepted: 8 March 2013

Published: 26 March 2013

\section{References}

1. Harada H, Kettunen P, Jung HS, Mustonen T, Wang YA, Thesleff I: Localization of putative stem cells in dental epithelium and their association with Notch and FGF signaling. J Cell Biol 1999, 147(1):105-120.

2. Tummers $\mathrm{M}$, Thesleff I: Observations on continuously growing roots of the sloth and the K14-Eda transgenic mice indicate that epithelial stem cells can give rise to both the ameloblast and root epithelium cell lineage creating distinct tooth patterns. Evol Dev 2008, 10(2):187-195.

3. Cobourne MT, Mitsiadis T: Neural crest cells and patterning of the mammalian dentition. J Exp Zoolog B Mol Dev Evol 2006, 306(3):251-260.

4. Knight RD, Schilling TF: Cranial neural crest and development of the head skeleton. Adv Exp Med Biol 2006, 589:120-133.

5. Noden DM, Schneider RA: Neural crest cells and the community of plan for craniofacial development: historical debates and current perspectives. Adv Exp Med Biol 2006, 589:1-23.

6. Peters H, Balling R T: Where and how to make them. Trends Genet 1999, 15(2):59-65

7. Thesleff I: Epithelial-mesenchymal signalling regulating tooth morphogenesis. J Cell Sci 2003, 116(9):1647-1648.

8. Thesleff I, Aberg T: Molecular regulation of tooth development. Bone 1999, 25(1):123-125.

9. Tucker AS, Sharpe PT: Molecular genetics of tooth morphogenesis and patterning: the right shape in the right place. J Dent Res 1999, 78(4):826-834.

10. Cobourne MT, Sharpe PT: Sonic hedgehog signaling and the developing tooth. Curr Top Dev Biol 2005, 65:255-287.

11. Dassule HR, Lewis P, Bei M, Maas R, McMahon AP: Sonic hedgehog regulates growth and morphogenesis of the tooth. Development 2000 127(22):4775-4785

12. Hardcastle Z, Hui CC, Sharpe PT: The Shh signalling pathway in early tooth development. Cell Mol Biol (Noisy-le-Grand) 1999, 45(5):567-578.

13. Nie X, Luukko K, Kettunen P: BMP signalling in craniofacial development. Int J Dev Biol 2006, 50(6):511-521.

14. Nie X, Luukko K, Kettunen P: FGF signalling in craniofacial development and developmental disorders. Oral Dis 2006, 12(2):102-111.

15. Pispa J, Mikkola ML, Mustonen T, Thesleff I: Ectodysplasin, Edar and TNFRSF19 are expressed in complementary and overlapping patterns during mouse embryogenesis. Gene Expr Patterns 2003, 3(5):675-679.

16. Tummers $M$, Thesleff I: The importance of signal pathway modulation in all aspects of tooth development. J Exp Zoolog B Mol Dev Evol 2009, 312B (4):309-319.

17. Thomas BL, Tucker AS, Qui M, Ferguson CA, Hardcastle Z, Rubenstein JL, Sharpe PT: Role of Dlx-1 and Dlx-2 genes in patterning of the murine dentition. Development 1997, 124(23):4811-4818.

18. Tucker AS, Al Khamis A, Sharpe PT: Interactions between Bmp-4 and Msx-1 act to restrict gene expression to odontogenic mesenchyme. Dev Dyn 1998, 212(4):533-539.

19. Mitsiadis TA, Drouin J: Deletion of the Pitx1 genomic locus affects mandibular tooth morphogenesis and expression of the Barx1 and Tbx1 genes. Dev Biol 2008, 313(2):887-896.

20. Mucchielli ML, Mitsiadis TA, Raffo S, Brunet JF, Proust JP, Goridis C: Mouse Ot|x2/RIEG expression in the odontogenic epithelium precedes tooth initiation and requires mesenchyme-derived signals for its maintenance. Dev Biol 1997, 189(2):275-284.

21. Lu MF, Pressman C, Dyer R, Johnson RL, Martin JF: Function of Rieger syndrome gene in left-right asymmetry and craniofacial development. Nature 1999, 401(6750):276-278.
22. Mark MP, Bloch-Zupan A, Ruch JV: Effects of retinoids on tooth morphogenesis and cytodifferentiations, in vitro. Int J Dev Biol 1992, 36(4):517-526.

23. Jernvall J, Thesleff I: Reiterative signaling and patterning during mammalian tooth morphogenesis. Mech Dev 2000, 92(1):19-29.

24. Tucker AS, Yamada G, Grigoriou M, Pachnis V, Sharpe PT: Fgf-8 determines rostral-caudal polarity in the first branchial arch. Development 1999, 126(1):51-61.

25. Coudert AE, Pibouin L, Vi-Fane B, Thomas BL, Macdougall M, Choudhury A, Robert B, Sharpe PT, Berdal A, Lezot F: Expression and regulation of the Msx1 natural antisense transcript during development. Nucleic Acids Res 2005, 33(16):5208-5218.

26. James $\subset$, Ohazama A, Tucker AS, Sharpe PT: Tooth development is independent of a Hox patterning programme. Dev Dyn 2002, 225(3):332-335.

27. Uchibe K, Shimizu H, Yokoyama S, Kuboki T, Asahara H: Identification of novel transcription-regulating genes expressed during murine molar development. Dev Dyn 2012, 241(7):1217-1226.

28. Barbosa AC, Funato N, Chapman S, McKee MD, Richardson JA, Olson EN, Yanagisawa $\mathrm{H}$ : Hand transcription factors cooperatively regulate development of the distal midline mesenchyme. Dev Biol 2007, 310(1):154-168.

29. Mitsiadis TA, Angeli I, James C, Lendahl U, Sharpe PT: Role of Islet1 in the patterning of murine dentition. Development 2003, 130(18):4451-4460.

30. Thesleff I, Jernvall J: The enamel knot: a putative signaling center regulating tooth development. Cold Spring Harb Symp Quant Biol 1997, 62:257-267.

31. Kollar EJ, Baird GR: The influence of the dental papilla on the development of tooth shape in embryonic mouse tooth germs. J Embryol Exp Morphol 1969, 21(1):131-148.

32. Kollar EJ, Baird GR: Tissue interactions in embryonic mouse tooth germs. II. The inductive role of the dental papilla. J Embryol Exp Morphol 1970, 24(1):173-186.

33. Caton J, Tucker AS: Current knowledge of tooth development: patterning and mineralization of the murine dentition. J Anat 2009, 214(4):502-515.

34. Fleischmannova J, Matalova E, Tucker AS, Sharpe PT: Mouse models of tooth abnormalities. Eur J Oral Sci 2008, 116(1):1-10.

35. Bloch-Zupan A, Sedano H, Scully C: Dento/Oro/Craniofacial Anomalies and Genetics. 1st edition. London: Elsevier Inc; 2012.

36. Hennekam JRCM, Krantz I, Allanson J: Gorlin's Syndromes of the Head and Neck. 5th edition. USA: Oxford University Press; 2010.

37. Gregory-Evans CY, Moosajee M, Hodges MD, Mackay DS, Game L, Vargesson N, Bloch-Zupan A, Ruschendorf F, Santos-Pinto L, Wackens G, et al: SNP genome scanning localizes oto-dental syndrome to chromosome $11 \mathrm{q} 13$ and microdeletions at this locus implicate FGF3 in dental and inner-ear disease and FADD in ocular coloboma. Hum Mol Genet 2007, 16(20):3482-3493.

38. Sirmaci A, Spiliopoulos M, Brancati F, Powell E, Duman D, Abrams A, Bademci G, Agolini E, Guo S, Konuk B, et al: Mutations in ANKRD11 Cause KBG Syndrome, Characterized by Intellectual Disability, Skeletal Malformations, and Macrodontia. Am J Hum Genet 2011, 89(2):289-294.

39. Rosenfeld JA, Ballif BC, Lucas A, Spence EJ, Powell C, Aylsworth AS, Torchia BA, Shaffer LG: Small deletions of SATB2 cause some of the clinical features of the 2q33.1 microdeletion syndrome. PLoS One 2009, 4(8):e6568.

40. Britanova O, Depew MJ, Schwark M, Thomas BL, Miletich I, Sharpe P, Tarabykin V: Satb2 haploinsufficiency phenocopies 2q32-q33 deletions, whereas loss suggests a fundamental role in the coordination of jaw development. Am J Hum Genet 2006, 79(4):668-678.

41. Bloch-Zupan A, Jamet X, Etard C, Laugel V, Muller J, Geoffroy V, Strauss JP, Pelletier V, Marion V, Poch O, et al: Homozygosity mapping and candidate prioritization identify mutations, missed by whole-exome sequencing, in SMOC2, causing major dental developmental defects. Am J Hum Genet 2011, 89(6):773-781.

42. Tissier-Seta JP, Mucchielli ML, Mark M, Mattei MG, Goridis C, Brunet JF: Barx1, a new mouse homeodomain transcription factor expressed in cranio-facial ectomesenchyme and the stomach. Mech Dev 1995, 51(1):3-15.

43. Nonomura K, Takahashi M, Wakamatsu Y, Takano-Yamamoto T, Osumi N: Dynamic expression of Six family genes in the dental mesenchyme and the epithelial ameloblast stem/progenitor cells during murine tooth development. J Anat 2010, 216(1):80-91.

44. Abe M, Tamamura Y, Yamagishi H, Maeda T, Kato J, Tabata MJ, Srivastava D, Wakisaka S, Kurisu K: Tooth-type specific expression of dHAND/Hand2: 
possible involvement in murine lower incisor morphogenesis. Cell Tissue Res 2002, 310(2):201-212

45. Haldeman-Englert CR, Biser A, Zackai EH, Ming JE: A 223-kb de novo deletion of PAX9 in a patient with oligodontia. J Craniofac Surg 2010, 21(3):837-839

46. Grigoriou M, Tucker AS, Sharpe PT, Pachnis V: Expression and regulation of Lhx6 and Lhx7, a novel subfamily of LIM homeodomain encoding genes, suggests a role in mammalian head development. Development 1998, 125(11):2063-2074

47. Li J, Huang X, Xu X, Mayo J, Bringas P Jr, Jiang R, Wang S, Chai Y: SMAD4mediated WNT signaling controls the fate of cranial neural crest cells during tooth morphogenesis. Development 2011, 138(10):1977-1989.

48. Lin D, Huang Y, He F, Gu S, Zhang G, Chen Y, Zhang Y: Expression survey of genes critical for tooth development in the human embryonic tooth germ. Dev Dyn 2007, 236(5):1307-1312.

49. Kettunen P, Furmanek T, Chaulagain $R$, Kvinnsland $I$, Luukko K: Developmentally regulated expression of intracellular Fgf11-13, hormone-like Fgf15 and canonical Fgf16, -17 and -20 mRNAs in the developing mouse molar tooth. Acta Odontol Scand 2011, 69(6):360-366.

50. Shoji H, Ito T, Wakamatsu Y, Hayasaka N, Ohsaki K, Oyanagi M, Kominami R, Kondoh $\mathrm{H}$, Takahashi N: Regionalized expression of the Dbx family homeobox genes in the embryonic CNS of the mouse. Mech Dev 1996, 56(1-2):25-39.

51. Shibaguchi T, Kato J, Abe M, Tamamura Y, Tabata MJ, Liu JG, Iwamoto M, Wakisaka S, Wanaka A, Kurisu K: Expression and role of Lhx8 in murine tooth development. Arch Histol Cytol 2003, 66(1):95-108.

52. Nadiri A, Kuchler-Bopp S, Perrin-Schmitt F, Lesot H: Expression patterns of BMPRs in the developing mouse molar. Cell Tissue Res 2006, 324(1):33-40.

53. Cho KW, Cai J, Kim HY, Hosoya A, Ohshima H, Choi KY, Jung HS: ERK activation is involved in tooth development via FGF10 signaling. J Exp Zool B Mol Dev Evol 2009, 312(8):901-911.

54. Cobourne MT, Miletich I, Sharpe PT: Restriction of sonic hedgehog signalling during early tooth development. Development 2004 131(12):2875-2885

55. Nakashima M, Toyono T, Murakami T, Akamine A: Transforming growth factor-beta superfamily members expressed in rat incisor pulp. Arch Oral Biol 1998, 43(9):745-751.

56. Wang W, Hart PS, Piesco NP, Lu X, Gorry MC, Hart TC: Aquaporin expression in developing human teeth and selected orofacial tissues. Calcif Tissue Int 2003, 72(3):222-227.

57. Iwasaki K, Bajenova E, Somogyi-Ganss E, Miller M, Nguyen V, Nourkeyhani H, Gao Y, Wendel M, Ganss B: Amelotin-a Novel Secreted, Ameloblastspecific Protein. J Dent Res 2005, 84(12):1127-1132.

58. Takahashi KF, Kiyoshima T, Kobayashi I, Xie M, Yamaza H, Fujiwara H, Ookuma Y, Nagata K, Wada H, Sakai T, et al: Protogenin, a new member of the immunoglobulin superfamily, is implicated in the development of the mouse lower first molar. BMC Dev Biol 2010, 10:115.

59. Aruga J: Slitrk6 expression profile in the mouse embryo and its relationship to that of NIrr3. Gene Expr Patterns 2003, 3(6):727-733.

60. Paiva KB, Silva-Valenzuela M, Massironi SM, Ko GM, Siqueira FM, Nunes FD: Differential Shh, Bmp and Wnt gene expressions during craniofacial development in mice. Acta Histochem 2010, 112(5):508-517.

61. Park KH, Han DI, Rhee YH, Jeong SJ, Kim SH, Park YG: Protein kinase C betall and delta/theta play critical roles in bone morphogenic protein-4 -stimulated osteoblastic differentiation of MC3T3-E1 cells. Biochem Biophys Res Commun 2010, 403(1):7-12.

62. Raju K, Tang S, Dube ID, Kamel-Reid S, Bryce DM, Breitman ML: Characterization and developmental expression of Tlx-1, the murine homolog of HOX11. Mech Dev 1993, 44(1):51-64.

63. Tahayato A, Dolle P, Petkovich M: Cyp26C1 encodes a novel retinoic acid-metabolizing enzyme expressed in the hindbrain, inner ear, first branchial arch and tooth buds during murine development. Gene Expr Patterns 2003, 3(4):449-454

64. Mizuno N, Shiba H, Xu WP, Inui T, Fujita T, Kajiya M, Takeda K, Hasegawa N, Kawaguchi $\mathrm{H}$, Kurihara $\mathrm{H}$ : Effect of neurotrophins on differentiation, calcification and proliferation in cultures of human pulp cells. Cell Biol Int 2007, 31(12):1462-1469.

65. Liu D, Yao S, Wise GE: Regulation of SFRP-1 expression in the rat dental follicle. Connect Tissue Res 2012, 53(5):366-372.
66. Liu D, Wise GE: A DNA microarray analysis of chemokine and receptor genes in the rat dental follicle-role of secreted frizzled-related protein-1 in osteoclastogenesis. Bone 2007, 41(2):266-272.

67. Maas R, Bei M: The genetic control of early tooth development. Crit Rev Oral Biol Med 1997, 8(1):4-39.

68. Uz E, Alanay Y, Aktas D, Vargel I, Gucer S, Tuncbilek G, von Eggeling F, Yilmaz E, Deren O, Posorski N, et al: Disruption of ALX1 causes extreme microphthalmia and severe facial clefting: expanding the spectrum of autosomal-recessive ALX-related frontonasal dysplasia. Am J Hum Genet 2010, 86(5):789-796

69. Biben C, Wang CC, Harvey RP: NK-2 class homeobox genes and pharyngeal/oral patterning: $\mathrm{Nkx2}-3$ is required for salivary gland and tooth morphogenesis. Int J Dev Biol 2002, 46(4):415-422.

70. Lezot F, Thomas B, Greene SR, Hotton D, Yuan ZA, Castaneda B, Bolanos A Depew M, Sharpe P, Gibson CW, et al: Physiological implications of DLX homeoproteins in enamel formation. J Cell Physiol 2008, 216(3):688-697.

71. Cobourne MT, Sharpe PT: Tooth and jaw: molecular mechanisms of patterning in the first branchial arch. Arch Oral Biol 2003, 48(1):1-14.

72. Sperber SM, Dawid IB: barx1 is necessary for ectomesenchyme proliferation and osteochondroprogenitor condensation in the zebrafish pharyngeal arches. Dev Biol 2008, 321(1):101-110.

73. Hardcastle Z, Mo R, Hui CC, Sharpe PT: The Shh signalling pathway in tooth development: defects in Gli2 and Gli3 mutants. Development 1998 125(15):2803-2811

74. Denaxa M, Sharpe PT, Pachnis V: The LIM homeodomain transcription factors Lhx6 and Lhx7 are key regulators of mammalian dentition. Dev Biol 2009, 333(2):324-336.

75. Tucker A, Sharpe P: The cutting-edge of mammalian development; how the embryo makes teeth. Nat Rev Genet 2004, 5(7):499-508.

76. Bloch-Zupan A, Decimo D, Loriot M, Mark MP, Ruch JV: Expression of nuclear retinoic acid receptors during mouse odontogenesis. Differentiation 1994, 57(3):195-203.

77. Bloch-Zupan A, Mark MP, Weber B, Ruch JV: In vitro effects of retinoic acid on mouse incisor development. Arch Oral Biol 1994, 39(10):891-900.

78. Charles C, Lazzari V, Tafforeau P, Schimmang T, Tekin M, Klein O, Viriot L: Modulation of Fgf3 dosage in mouse and men mirrors evolution of mammalian dentition. Proc Natl Acad Sci U S A 2009, 106(52):22364-22368.

79. Kantaputra PN, Gorlin RJ: Double dens invaginatus of molarized maxillary central incisors, premolarization of maxillary lateral incisors, multituberculism of the mandibular incisors, canines and first premolar, and sensorineural hearing loss. Clin Dysmorphol 1992, 1(3):128-136.

80. Charles C, Hovorakova M, Ahn Y, Lyons DB, Marangoni P, Churava S, Biehs B, Jheon A, Lesot $H$, Balooch $G$, et al: Regulation of tooth number by finetuning levels of receptor-tyrosine kinase signaling. Development 2011, 138(18):4063-4073.

81. Edgar R, Domrachev M, Lash AE: Gene Expression Omnibus: NCBI gene expression and hybridization array data repository. Nucleic Acids Res 2002, 30(1):207-210

doi:10.1186/1756-0500-6-113

Cite this article as: Laugel-Haushalter et al:: Molars and incisors: show your microarray IDs. BMC Research Notes 2013 6:113.

\section{Submit your next manuscript to BioMed Central and take full advantage of:}

- Convenient online submission

- Thorough peer review

- No space constraints or color figure charges

- Immediate publication on acceptance

- Inclusion in PubMed, CAS, Scopus and Google Scholar

- Research which is freely available for redistribution 